\title{
A New Permian Bivalve (Megadesmidae, Plesiocyprinellinae) from the Serrinha Member, Rio do Rasto Formation, Paraná Basin, Brazil Um Novo Bivalve Permiano (Megadesmidae, Plesiocyprinellinae) do Membro Serrinha (Formação Rio do Rasto), Bacia do Paraná, Brasil
}

\author{
Luiz Eduardo Anelli' (anelli@usp.br), Marcello Guimarães Simões² (btsimoes@ibb.unesp.br), \\ Juliana Machado David ${ }^{3}$ (juliana_mdavid@yahoo.com.br) \\ 'Departamento de Geologia Sedimentar e Ambiental - Instituto de Geociências - USP \\ R. do Lago 562, CEP 05508-080, São Paulo, SP, BR \\ ${ }^{2}$ Instituto de Biociências - UNESP, Botucatu, SP, BR \\ ${ }^{3}$ Instituto de Geociências e Ciências Exatas - UNESP, Rio Claro, SP, BR
}

Received 24 August 2009; accepted 11 January 2010

\begin{abstract}
During a recent inspection in the Paleontological Collection of the Institute of Geosciences, University of São Paulo, we have identified some specimens of undescribed mollusk bivalves. These called our attention for the following reasons: a) all specimens are internal molds of conjugated and closed articulated valves, some of them presenting fragments of silicified shells; b) all internal molds have similar general shape and internal characters, representing specimens of the same taxon; c) the internal molds and silicified valves are well preserved, including fragile structures, which are hardly preserved, such as the internal mold of the external ligament and muscle scars; d) and equally important, according to the labels of all specimens, they were collected from rocks of the Passa Dois Group (Permian), Serrinha Member of the Rio do Rasto Formation. Although who collected the shells and the precise geographic location of the specimens are still unknown, the detailed study of these fossils brings us to the conclusion that they are morphologically distinct from any heretofore published genus of the endemic fauna of bivalves from Passa Dois Group. Based in its general shape, hinge structure and muscles scars, the new form can be classified under the Family Megadesmidae Vokes, 1967, the most diverse group of Permian bivalves of the Paraná Basin. The specimens are referred as Beurlenella elongatella new gen. and sp. The shell shape and taphonomy indicate that this bivalve was a shallow, rapid, active burrower, suspension feeder, probably preserved in situ, in event deposits.
\end{abstract}

Keywords: Bivalvia; Megadesmidae; Permian; Paraná Basin; Serrinha Member; Rio do Rasto Formation.

\section{RESUMO}

Durante recente organização das coleções paleontológicas do Laboratório de Paleontologia Sistemática do Instituto de Geociências, Universidade de São Paulo, foram localizados alguns espécimes de moluscos bivalves, ainda não descritos, que chamaram nossa atenção pelas seguintes razões: a) todos os espécimes são moldes internos de valvas conjugadas, articuladas fechadas, alguns destes com restos da concha silicificada; b) todos os moldes internos têm a mesma forma geral e características internas, representando espécimes de um mesmo táxon; c) os moldes internos e as valvas silicificadas estão bem preservadas, e incluem estruturas frágeis de difícil preservação, tais como o molde interno do ligamento externo e também as cicatrizes musculares; d) e igualmente importante, todos os espécimes estão registrados como provenientes das rochas do Grupo Passa Dois (Permiano), Membro Serrinha, da Formação Rio do Rasto. Embora não existam informações sobre o autor da coleta e localização geográfica dos espécimes, o estudo detalhado da morfologia desses fósseis evidencia tratar-se de um gênero de bivalve distinto dos já descritos para a fauna endêmica do Grupo Passa Dois. Fundamentado na forma geral da concha, estrutura da charneira e cicatrizes musculares, o novo táxon é atribuído 
à Família Megadesmidae Vokes, 1967, a mais diversificada dentre aquelas do Permiano da Bacia do Paraná. Os espécimes são aqui designados como Beurlenella elongatella gênero e espécie novos. A forma geral dos espécimes, bem como o modo de preservação, indica que se trata de um bivalve escavador raso ativo, rápido, suspensívoro, que foi provavelmente preservado in situ, em depósitos gerados por sedimentação episódica.

Palavras-chave: Bivalvia; Megadesmidae; Permiano; Bacia do Paraná; Membro Serrinha; Formação Rio do Rasto.

\section{INTRODUCTION}

The classical endemic, Permian molluscan fauna of the Passa Dois Group, Paraná Basin (Mendes, 1952; Runnegar and Newell, 1971; Simões, Rocha-Campos, Anelli, 1998) includes, according to the present knowledge, the following biozones(Rohn, 1994)instratigraphicsuccession:Anhembia froesi (Serra Alta and Corumbataí formations), Pinzonella illusa (Teresina and Corumbataí formations), Pinzonella neotropica (Teresina and Corumbataí formations), Leinzia similis (Rio do Rasto Formation, Serrinha Member), and Palaeomutela? platinensis (Rio do Rasto Formation, Morro Pelado Member). Most of the previous studies have dealt with the systematics, paleoecology and taphonomy of bivalves of the Pinzonella illusa and Pinzonella neotropica biozones, where the shells are usually silicified and well preserved (Torello and Simões, 1994; Simões and Anelli, 1995; Simões, Torello, Rocha-Campos, 1996; Simões et al., 1997; Simões, Rocha-Campos, Anelli, 1998; Simões and Kowalewski, 1998; Ghilardi, 1999; Mello, 1999; Kowalewski et al., 2000; Ghilardi and Simões, 2002; Simões et al., 2000; Simões and Torello, 2003). Less well known are the faunas of the Serra Alta Formation (Anhembia froesi Biozone, Maranhão and Petri, 1996), and Serrinha (Leinzia similis Biozone) and Morro Pelado (Palaeomutela? platinensis Biozone) members, of the Rio do Rasto Formation. Actually, despite the exhaustive studies of Rohn $(1985,1988,1994)$, and a short note in Rohn and Simões (1997), the bivalves of the Serrinha Member of the Rio do Rasto Formation are still poorly studied, described and drawn (Mendes, 1954; Rohn, 1994; Rohn and Simões, 1997). Several lines of evidences suggest that the bivalve fauna of the Serrinha Member is more diverse than previously reported in the literature (see, for example, Rohn, 1994; Rohn and Simões, 1997). In fact, during a recent examination of the bivalve collection of the Institute of Geosciences, University of São Paulo a considerable number of forgotten, and undescribed bivalve specimens of the Serrinha Member were found. These specimens were donated to Professor Josué Camargo Mendes (Institute of Geosciences, University of São Paulo) in the seventies, when he immediately recognized the importance of those specimens, due to their good preservation (A. C. RochaCampos, personal communication, 2009). However, for unknown reasons, J. C. Mendes was not able to study those bivalves, and since then, they have been forgotten. In the present study, we describe these bivalves with the following purposes: first, to add new systematic information about the bivalve fauna of the Serrinha Member; second, to show that the examination of this interval harbors bivalves could provide relevant taphonomical and paleoecological information, and finally, to call attention of geologists and paleontologists working with the Rio do Rasto Formation to the possible occurrence of unknown fossil material.

\section{MATERIAL AND METHODS}

As mentioned above, all specimens herein described are housed in the Scientific Collection of the Institute of Geosciences, University of São Paulo, São Paulo, under the code GP/1E. Although the specimens had been extracted from the rock matrix prior to their addition to that collection, the internal molds are made of grayish mudstone, which is the same matrix infilling of the closed articulated silicified shells. The type of preservation and lithology of the internal molds seem to be similar to that of bivalve-rich horizons found in the basal portion of Serrinha Member (see Rohn, 1994; Warren et al., 2008). However, the specimens were labeled only as placed in Passa Dois Group, Serrinha Member. Hence, the exact location and stratigraphic horizon where the specimens were collected are still unknown.

In total, ten bivalve specimens were studied and all of them are internal molds of conjugated valves of closed articulated shells. This set of specimens consists of three internal molds with silicified shell remains, six internal molds (two are almost completely preserved internal molds and four have the posterior end of the shell missing) and one deformed internal mold (dorsoventrally compressed). Plasticine casts and impregnation with magnesium show internal anatomical characters of the examined specimens, including muscle scars and hinge features. Finally, the suprageneric systematics is based on Morris, Dickins and Astafieva-Urbaitis (1991), and, at the family level, on Runnegar and Newell (1971), Runnegar (1974), and Simões et al. (1997). Shell obesity and elongation indexes were calculated according to Stanley (1970). 


\section{SYSTEMATIC PALEONTOLOGY}

Subclass HETEROCONCHIA Hertwig, 1895

Superorder ANOMALODESMATA Dall, 1899

Order PHOLADOMYOIDA Newell, 1965

Superfamily PHOLADOMYOIDEA (King, 1844) Gray, 1847

Family MEGADESMIDAE Vokes, 1967

Subfamily PLESIOCYPRINELLINAE Simões et al., 1997

Comments. Runnegar and Newell (1971) assigned to Megadesmidae Vokes, 1967 the bivalves that yield robust and nacreous shells, with short siphons, a stout external ligament, lacking teeth or with a blunt tooth in the right or both valves. Simões et al. (1997) performed a cladistic analysis on the monophyly of the Family Megadesmidae and found it supported only by the blunt tooth of the right valve. The bivalve shells from the Serrinha Member have short and distinct nymph and a well marked blunt tooth in the right valve. These features suggest that the specimens belong to the Family Megadesmidae Vokes (1967). The absence of the accessory muscle scars (a, b, ava, see Runnegar, 1966 , 1974) suggests affinities to the Subfamily Plesiocyprinellinae (Simões et al., 1997).

\section{Genus Beurlenella new genus}

Figures 1, 2, Table 1

Type-species. Beurlenella elongatella $\mathrm{n}$. gen. and sp.

Diagnosis. Megadesmid very elongate posteriorly; anterior margin rounded and expanded. Umbonal ridge well defined, slightly curved, located very close to posterior dorsal margin. A well developed blunt tooth is present in the right valve.

Etymology. It is named Beurlenella in honor of the eminent German geologist Karl Beurlen (1901 - 1985), in recognition of his contribution to the knowledge of the paleontology and stratigraphy of the Gondwana sequence of the Paraná Basin (states of Paraná, Santa Catarina and Rio Grande do Sul), Brazil. Data gathered by K. Beurlen during the fifties provided some clues to understating of the evolution of the endemic molluscan fauna of the Passa Dois Group, Permian.

Remarks. The new genus Beurlenella has several characters that make it very distinct from other endemic bivalve species from the Permian Paraná Basin. Actually, the shells of Beurlenella share a set of common characters that, isolated, can be seen in distinct megadesmids of the Passa Dois Group. For example, the shells of Beurlenella are elongated; a feature also noted in Jacquesia Mendes, 1944, Favalia Mendes, 1962, and Houdhausiella Mendes, 1952, but, on the other hand, these shells are edentulous or have a poorly developed megadesmid blunt tooth in the right valve. Carinate, elongated shells are also found in Leinzia (Holdhaus, 1918) and Anhembia (Mendes, 1949), but a remarkable rostrum, which is absent in Beurlenella, is present in the anterior extremity of these shells. Although Plesiocyprinella Holdhaus, 1918, and Ferrazia Reed, 1932 have a well developed megadesmid tooth in the right valve, just like Beurlenella does, those shells are not elongate. In addition to that, Ferrazia has a completely distinct ornamentation.

\section{Beurlenella elongatella new species Figures $1 \mathrm{~A}$ to $1 \mathrm{~K}, 1 \mathrm{M}, 1 \mathrm{~N}, 2$}

Holotype. GP/1E 4816.

Comments: The holotype specimen GP/1E 4816 (Figures 1A to 1E) is an internal mold, which comprises a preserved and nearly complete silicified right valve, showing the expanded anterior region of shell, the umbonal carina located close to the posterior dorsal margin and the internal mold of the parivincular ligament.

Paratypes. GP/1E 4815, 4817, 4818, 4919, 4920, 4021, 4022, 4823, 4825.

Comments. Plasticine casts of hinge area of paratypes GP/1E 4815 (Figures $1 G$ to $1 \mathrm{I}$ ) and GP/1E 4825 (Figures $1 \mathrm{~J}, 1 \mathrm{~K}$ ) clearly show the presence of megadesmid blunt in their right valves (arrows).

Diagnosis. As for the genus (see above).

Etymology: elongatella, referring to the posteriorly elongated nature of Beurlenella shells.

Stratigraphy. Passa Dois Group, Serrinha Member (?), Rio do Rasto Formation, eastern margin of the Paraná Basin.

Locality. Unknown.

Age. Permian, Guadalupian to Early Lopingian.

Description. Megadesmid shell of medium size, varying in length from $44-49 \mathrm{~mm}$ for incomplete specimens (see Table 1), thick, equivalve, inequilateral, very elongate posteriorly, moderate inflated, non-gaped anteriorly. Posterior end of the shell unknown. Umbones low, slightly prosogyrous; postero-umbonal ridge, slightly curved, well defined but slender, located very close to posterior dorsal margin. Lunule absent; escutcheon very narrow. Ligament short, opisthodetic, parivincular, external, attached to a very slender nymph placed deep on the anterior portion of the escutcheon. Anterior margin expanded androunded; ventral margin anteriorly convex and straight posteriorly; dorsal margin straight. Surface ornament of well-marked, irregularly spaced comarginal growth lines of varying width. Hinge of right valve with a well defined blunt tooth; left valve with a well defined socket. Posterior adductor 
and pedal retractor scars well defined, not connected to the adductor. Anterior adductor muscle scars and pallial line not observed.

Discussion. The new species from Paraná Basin here described presents robust valves and a blunt tooth in the right valve, features that properly include them in the Family Megadesmidae. The elongated nature of their shells is also observed in other elements of the endemic fauna of the Passa Dois Group, such as Holdhausiella (Holdhaus) and Jacquesia (Reed). However, in these genera, the hinge is edentulous (Holdhausiella) or with a poorly developed megadesmid tooth in the right valve (Jacquesia). These hinge characteristics are in remarkable contrast with those shown by Beurlenella elongatella, where the megadesmid tooth is well developed. $B$. elongatella resembles Favalia arcuata in general shell shape (see Runnegar and Newell, 1971, p. 43, fig. 17b, e), but its shells are thicker and its obesity index is higher. In addition, the shells of $F$. arcuata are edentelous. Finally, the size and position of the opistodetic ligament in $B$. elongatella are very similar to that observed in Plesiocyprinella (see Figures 1D, 1L).

\section{TAPHONOMY, PALEOECOLOGY AND FACIES ASSOCIATION}

As demonstrated by Stanley $(1970,1972)$, Kondo (1987, 1989) and Ghilardi and Simões (2000), the biostratinomy and functional anatomy of infaunal bivalves are potential sedimentological tools for stratigraphical analyzes. In this context, the mode of preservation and the paleoautoecology of the shells of Beurlenella elongatella can provide several clues about the kind of strata where they were preserved, despite the fact this information is missing.

Beurlenella elongatella is a very elongated, compressed to moderately inflated, non-gaped shell, with a broad anterior margin that may have accommodated a large foot during life. Hence, the anatomy of $B$. elongatella indicates that this species was an active, rapid, suspension-feeder and shallow burrower (see Stanley, 1970). In this context, the life habit of $B$. elongatella was similar to that of other megadesmids with posteriorly elongated shells, such as Myonia, Holdhausiella and Jacquesia, except, perhaps, by the fact that the new species was a rapid burrower. As suggested by Stanley (1970), recent bivalves with very

Table 1. Measurements ( $\mathrm{mm}$ ) of Beurlenella elongatella new gen. and sp.

\begin{tabular}{ccccccc}
\hline Specimen Code & Valve & Length & Height & Width & $\begin{array}{c}\text { Eongation } \\
\text { L/H }\end{array}$ & $\begin{array}{c}\text { Obesity } \\
\text { H/W }\end{array}$ \\
\hline GP/1T 4818 & R/L & 49.68 & 25.88 & - & 1.92 & - \\
GP/1T 4816 & R/L & 44.20 & 26.51 & 15.19 & 1.67 & 1.74 \\
GP/1T 4825 & R/L & - & 27.74 & 17.74 & - & 1.56 \\
GP/1T 4815 & R/L & - & 28.72 & 17.76 & - & 1.62 \\
GP/1T 4817 & R/L & - & 24.03 & 14.33 & - & 1.68 \\
GP/1T 4920 & R/L & - & 27.42 & - & - & - \\
\hline
\end{tabular}

Figure 1. A-K, M-N, Beurlenella elongatella new gen. and sp., Passa Dois Group, Serrinha Member, Paraná Basin, Permian. All specimens $x 1.3$. A. Incomplete silicified internal mold with silicified shell remains, right valve view, GP/1E 4816. B. Internal mold with fragments of silicified shell, left valve view, same specimen. C. Anterior view, same specimen. D. Dorsal view, same specimen, with the internal mold of the ligament preserved (arrow). E. Drawing representation of the dorsal view, same specimen. F. Incomplete internal mold, left side view, GP/1E 4815. G. Ventral view, same specimen. H. Dorsal view, same specimen showing hinge region. I. Plasticine mold, internal view of articulated hinge region, showing the blunt tooth of right valve (arrow), based on the same specimen. J. Internal mold showing the posterior part of shell covered with silicified shell, dorsal view, GP/1E 4825. K. Plasticine mold, internal view of articulated hinge region, showing the blunt tooth of right valve (arrow), based on the same specimen. L. Plesiocyprinella carinata (Holdhaus) 1918, Corumbataí Formation, Upper Permian; silicified articulated shell, dorsal view showing the silicified ligament (arrow), DZP-681. M. Almost dorsoventraly compressed internal mold, right side view, GP/1E 4822. N. Dorsal view, same specimen. 

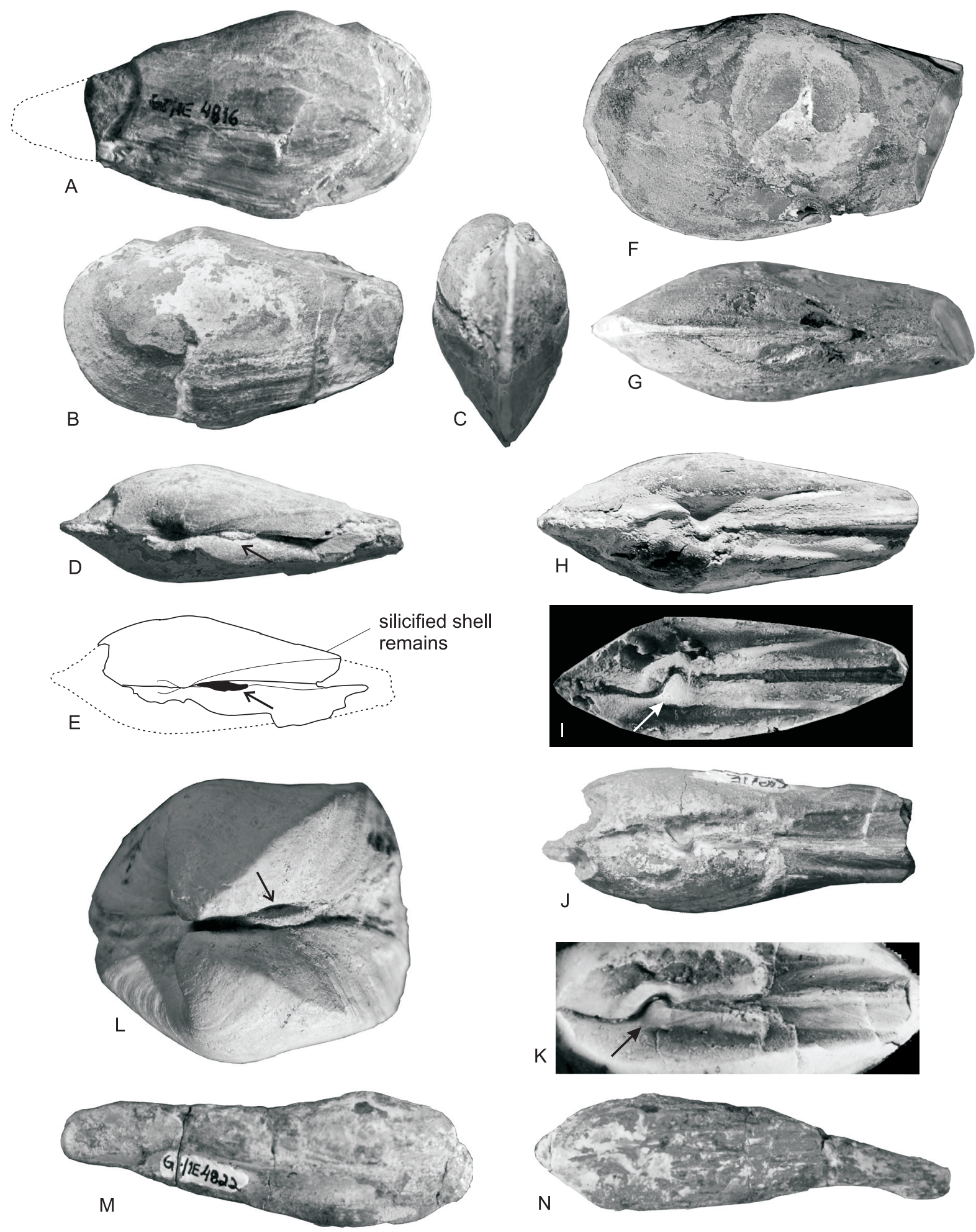

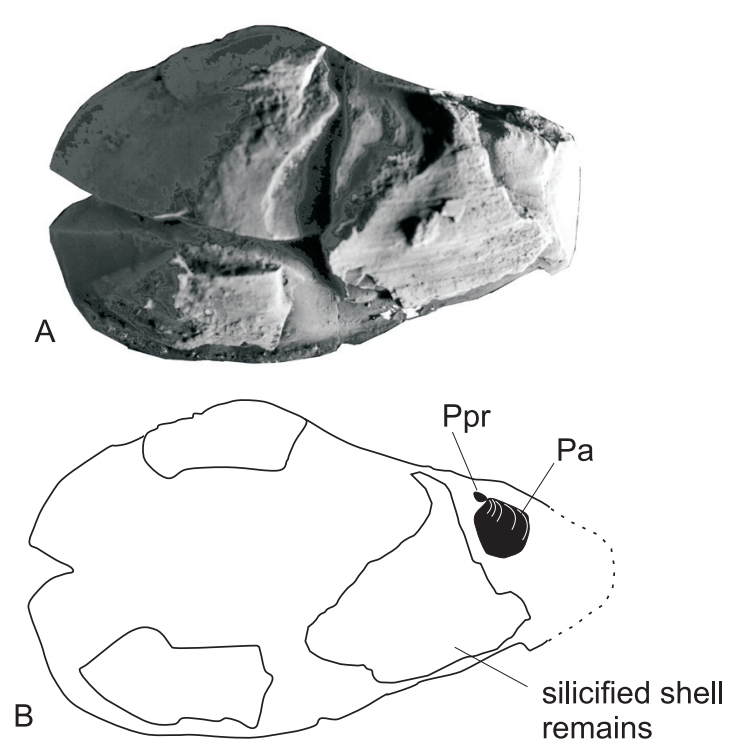
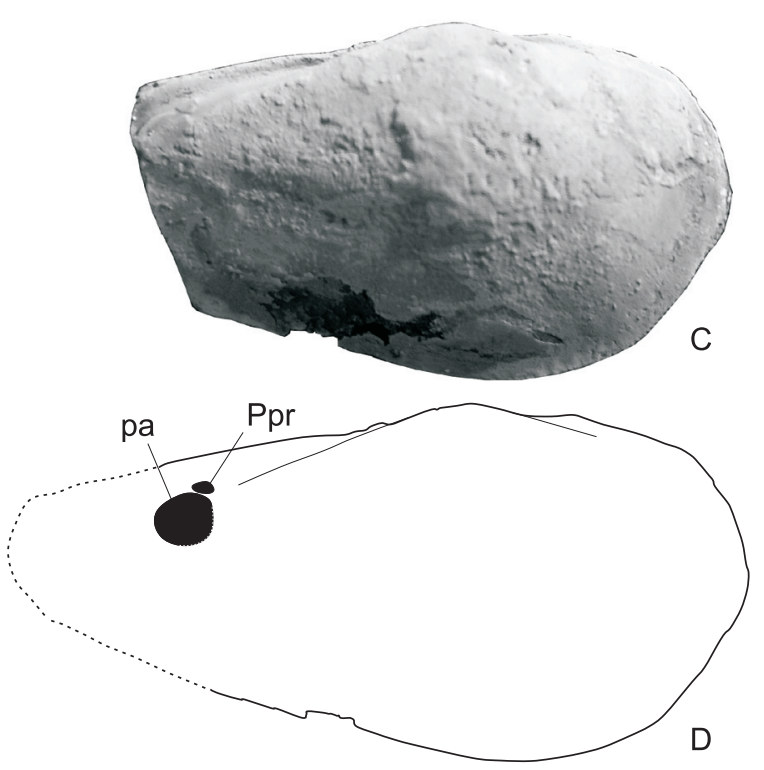

Figure 2. Beurlenella elongatella new gen. and sp., Passa Dois Group, Serrinha Member, Paraná Basin, Upper Permian. All specimens x1.3. A. Fragmentary internal mold with silicified shell remains, left side view, GP/1E 4819. B. Muscle scars based in the same specimen. C. Fragmentary internal mold, right side view, GP/1E 4815. D. Muscle scars based on the same specimen. Muscles scar, ppr = posterior pedal retractor, $\mathbf{p a}=$ posterior adductor .

elongated valves use very little or no rocking movement (see also Rocha-Campos and Simões, 1993) and the foot of these bivalves normally emerges in a direction parallel to the long axis of the shell. In this way, the mode of life of $B$. elongatella was probably with its shell positioned with the main axes nearly perpendicular to bedding. It was inferred that the mode of life of Late Paleozoic megadesmids was similar (see Rocha-Campos and Simões, 1993). Since the shells keep the same position when burrowing into the sediment (Stanley, 1970), bivalves with very elongated shells are preserved in situ, within the substrate, in the same position (see Anelli, Simões, Rocha-Campos, 1998). In other words, erosional and rapid depositional events can be identified based only on the preserved position of the infaunal bivalve shells (Ghilardi and Simões, 2000). Finally, like other megadesmids, $B$. elongatella was probably a suspension-feeder bivalve, indicating that food resources were dominantly in suspension in the water.

The taphonomy and functional morphology of Paleozoic marine bivalves are well known from a number of papers (see a review in Ghilardi, 1999). Most of shellrich beds from Paleozoic epeiric seas (see, for example, Brett and Baird, 1986), as was the case of Paraná Basin during the Mid Permian, were formed under the influence of storms (see Torello and Simões, 1994; Simões, Torello, Rocha-Campos, 1996, Simões et al., 2000; Simões and Kowalewski, 1998; Simões and Torello, 2003). As discussed by Kondo (1997), storm process may be erosional or depositional, depending on the environment and severity of the storm. In shallow water (well above storm wave base), or in very shallow seas (as it was the case of Paraná Basin), a large amount of sediment may be removed during storms, causing infaunal disruption. On the middle to lower shelf (well below the normal wave base), however, there may be rapid deposition of suspended muddy blankets after a storm, without significant erosion or substrate disruption. Thus, the sedimentological and taphonomical record of bivalve shells within a stormdominated succession will differ greatly, depending on the position with respect to water depth or storm wave base (see Rodrigues, Simões, Leme, 2003, for a similar pattern with Paleozoic cnidarians).

As demonstrated by various authors (Seilacher, 1982; Seilacher, Reif, Westphal, 1985; Brett and Baird, 1986; Brett, 1990; Brett and Seilacher, 1991; Anelli, Simões, Rocha-Campos, 1998; Simões and Kowalewski, 1998), infaunal bivalves preserved in situ are invariably associated to storm events, especially obrution deposits. The shells of B. elongatella are conjoined and pristine. Although the original position in the rock matrix is missing, the fact that the shells are closed articulated, without signs of abrasion, fragmentation, and encrustation, indicates that those shells 
were not exposed to the sediment/water interface. In summary, there are no signs that $B$. elongatella shells were repeatedly washed out and transported, which ultimately indicates that the shells were probably preserved in deposits generated just in and/or below storm wave base, probably in distal tempestites (obrution deposits).

Hummocky and swaley cross-stratification, which have often been pointed out as sedimentary structures characteristic of storm events, are in fact the unique sedimentary structures originated during storm sedimentation. Therefore we may search in the stratigraphical record of the Rio do Rasto Formation for the most plausible interval where storm sedimentation prevails. These intervals are likely to preserve bivalve shells with similar taphonomic signatures, as those found in the shells of $B$. elongatella. According to Warren et al. (2008), the lower portion of the Rio do Rasto Formation is characterized by beds that were deposited in offshore environments subjected to storm action (see also Rohn, 1994). These rocks are part of storm-dominated facies, where sandstones with hummocky cross-stratification and heterolitic mudstones are common (Warren et al., 2008). This lower portion of the Rio do Rasto Formation is part of the interval of the Serrinha Member, the same assigned in the label of our examined specimens. According to Rohn (1994) and Rohn and Simões (1997), the base of the Serrinha Member is, in part, the interval of the Leinzia similis Biozone, but when considering the examined collection, typical members of this biozone are missing. However, Rohn and Simões (1997) have defined a distinct (unnamed) bivalve biozone in the basal portion of the Serrinha Member, which is a little older than the typical Leinzia similis Biozone. The bivalves from this interval are commonly preserved as molds in green-yellowish shale, as articulated valves, either closed or butterflied, some probably preserved in situ (Rohn and Simões, 1997). Hence, the taphonomical conditions of the bivalve shells present in this basal interval are similar to that of the specimens herein described. Alternatively, however, it should be remembered that the fact that the studied shells are close articulated does not exclude per se the possibility of an occurrence of these shells in the strata of the Morro Pelado Member of the Rio do Rasto Formation. This is explained by the fact that some shells of the Palaeomutela? platinensis Biozone (above the Serrinha Member) were also found articulated (Rohn, 1994), indicating they were abruptly buried by sediments associated to turbulent hyperpycnal flows, such as at river mouths in lakes (R. Rohn, personal communication, 2009). Unfortunately, only further research can confirm or refute the assertion above mentioned, named the identification of bivalve shells preserved in situ in storm deposits in the basal portion of the Rio do Rasto Formation (Serrinha Member), or otherwise in marginal lacustrine to fluvial deposits in the mid portion of this unit (Morro Pelado Member). Since the studied specimens were labeled as "Serrinha Member", the first option seems to be the most plausible in light of the information available.

\section{FINAL REMARKS}

All the examined specimens were referred to the new megadesmid genus and species Beurlenella elongatella. It is not a surprise that the small assemblage studied here is dominated by megadesmid bivalves, since this group was the most diverse and abundant in the Paraná Basin during Permian times. Hence, our data is not only another indication of the dominance of Megadesmidae in the Passa Dois Group fossil record, but also a remarkable evidence of the morphological disparity showed in this group of Permian bivalves of the Paraná Basin. Therefore, we assign this new element to the Serrinha Member molluscan fauna.

\section{ACKNOWLEDGEMENTS}

We would like to thank CNPq and FAPESP for the financial support. This study is a contribution to the following projects: FAPESP (96/9708-9), and CNPq (500694/92-3, 151853/2008-8). The final version of this paper was improved, thanks to helpful and constructive comments of R. Rohn and an anonymous reviewer.

\section{REFERENCES}

ANELLI, L. E.; SIMÕES, M. G.; ROCHA-CAMPOS, A. C. Life mode of some Brazilian Upper Paleozoic anomalodesmatans. In: JOHNSTON, P. A; HAGGART, J. W. Bivalves: An Eon of evolution - Paleobiological Studies in Honoring of Norman D. Newell. Calgary: University of Calgary Press, 1998. p. 65-74.

BRETT, C. E. Obrution deposits. In: BRIGGS, D. E. G.; CROWTHER, P. R. Palaeobiology, a Synthesis. Oxford: Blackwell, 1990. p. 239-243.

BRETT, C.; BAIRD, G. C. Comparative taphonomy: a key to paleoenvironmental interpretation based on fossil preservation. Palaios, v. 1, p. 207-227, 1986.

BRETT, C. E.; SEILACHER, A. Fossil Lagerstatten: a taphonomic consequence of event sedimentation. In: EINSELE, G. et al., Cycles and Events in Stratigraphy. Berlin: Springer, 1991. p. 283-297.

GHILARDI, R. P. Paleoautoecologia dos bivalves do Grupo Passa Dois (Neopermiano), no Estado de São 
Paulo: bivalves fósseis como indicadores da dinâmica sedimentar. 1999. 160 f. Dissertação (Mestrado) - Instituto de Geociências, Universidade São Paulo, São Paulo, 1999 .

GHILARDI, R. P.; SIMÕES, M. G. Bivalves fósseis como indicadores da dinâmica sedimentar: um estudo de casos do Permiano da Bacia do Paraná, Brasil. Acta Geologica Leopoldensia, v. 23, n. 51, p. 3-20, 2000.

GHILARDI, R. P.; SIMÕES, M. G. Foram os bivalves do Grupo Passa Dois (Exclusive Formação Rio do Rasto), Neopermiano, invertebrados tipicamente dulcícolas? Pesquisas em Geociências, v. 29, p. 91-99, 2002.

HOLDHAUS, K. Sobre alguns lamelibranchios fósseis do sul do Brasil. Serviço Geológico e Mineralógico, Monografia 2, 1918. p. 1-24.

KONDO, Y. Burrowing depth of infaunal bivalvesobservation of living species and its relation to shell morphology. Transactions and Proceedings of the Palaeontological Society of Japan, v. 148, p. 306-323, 1987.

KONDO, Y. A method of analysing mode of occurrence of bivalve fossils-comparison of position and orientation of living and fossil bivalves. Benthos Research, v. 37, p. 73-82, 1989.

KONDO, Y. Inferred bivalve response to rapid burial in a Pleistocene shallow-marine deposit from New Zealand. Palaeogeography, Palaeoclimatology, Palaeoecology, v. 128, p. 87-100, 1997.

KOWALEWSKI, M.; SIMOES, M. G.; TORELLO, F. F.; MELLO, L. H. C ; GHILARDI, R. P.Drill holes in shells of Permian benthic invertebrates. Journal of Paleontology, v. 74, p. 532-543, 2000.

MARANHÃO, M. S. A. S.; PETRI, S. Novas ocorrências de fósseis nas formações Corumbataí e Estrada Nova do Estado de São Paulo e considerações preliminares sobre seus significados paleontológicos e bioestratigráfico. Revista do Instituto Geológico, São Paulo, v. 17 , p. 33-54, 1996.

MELLO, L. H. C. Análise cladística dos bivalves do Grupo Passa Dois (Neopermiano), Bacia do Paraná, Brasil: implicações taxonômicas, evolutivas e paleobiogeográficas. 1999. 160 f. Dissertação (Mestrado) Instituto de Geociências, Universidade São Paulo, São Paulo, 1999.
MENDES, J. C. Lamelibrânquios triássicos de Rio Claro. Boletim da Faculdade de Filosofia Ciências e Letras. Série Geologia, v. 45, v. 1, p. 41-75, 1944.

MENDES, J. C. Novos lamelibrânquios fósseis da Série Passa Dois, Sul do Brasil. Boletim da Divisão de Geologia e Mineralogia, DNPM, v. 133, p. 1-40, 1949.

MENDES, J. C. A Formação Corumbataí na região do Rio Corumbataí (estratigrafia e descrição dos lamelibrânquios). Boletim da Faculdade de Filosofia Ciências e Letras. Série Geologia, v. 145, p. 1-119, 1952.

MENDES, J. C. Contribuição à estratigrafia da Série Passa Dois no Estado do Paraná. Boletim da Faculdade de Filosofia Ciências e Letras Série Geologia, v. 175, p. 1-119, 1954.

MENDES, J. C. Lamelibrânquios permianos do oólito de Angatuba, estado de São Paulo (Formação Corumbataí). Boletim da Sociedade Brasileira de Geologia, v. 11, n. 1, p. 37-56, 1962.

MORRISN.J.;DICKINS, J.M.;ASTAFIEVA-URBAITIS, K. Upper Paleozoic Anomalodesmatan Bivalvia. Bulletin of the British Museum of Natural History (Geology), v. 47, p. 51-100, 1991.

REED, F. R. C. Some new Triassic fossils from Brazil. Annals and Magazine of Natural History, v. 10, n. 10, p. 479-487, 1932.

ROCHA-CAMPOS, A. C.; SIMÕES, M. G. Australomya sinuosa sp.n., um novo Megadesmídeo (Mollusca, Pelecypoda) da Formação Rio Bonito (Permiano), Bacia do Paraná, Brasil. Anais da Academia Brasileira de Ciências, v. 65, n. 1, p. 29-39, 1993.

RODRIGUES, S. C.; SIMÕES,M. G.; LEME, J. M. Tafonomia comparada dos Conulate (Cnidária), Formação Ponta Grossa (Devoniano), Bacia do Paraná, Estado do Paraná. Revista Brasileira de Geociências, v. 33, n. 4, p. 381-390, 2003.

ROHN, R. Bivalves da Formação Rio do Rasto (Permiano Superior) no Estado do Paraná. In: CONGRESSO BRASILEIRO DE PALEONTOLOGIA, 9., 1985, Fortaleza. Resumos... Rio de Janeiro: Sociedade Brasileira de Paleontologia, 1985. v. 1, p. 134.

ROHN, R. Bioestratigrafia e paleoambientes da Formação Rio do Rasto na borda leste da Bacia do Paraná (Per- 
miano Superior, estado do Paraná). 1988. 2v. Dissertação (Mestrado) - Instituto de Geociências, Universidade São Paulo, São Paulo, 1988.

ROHN, R. Evolução ambiental da Bacia do Paraná durante o Neopermiano no leste de Santa Catarina e do Paraná. 1994. 2v. Tese (Doutorado)- Instituto de Geociências, Universidade São Paulo, São Paulo, 1994.

ROHN, R.; SIMOES, M. G. Pelecypods of the basal Serrinha Member (Rio do Rasto Formation, Passa Dois Group, Upper Permian) at the Reserva-Cândido de Abreu region of the Paraná State. In: CONGRESSO BRASILEIRO DE PALEONTOLOGIA, 15, 1997, São Pedro. Boletim de Resumos...São Pedro: SBG, 1997, p. 72.

RUNNEGAR, B. Systematic and biology of some desmodont bivalves from the Australian Permian. Journal of Geological Society of Australia, v. 13, n. 2, p. 373-386, 1966.

RUNNEGAR, B. Evolutionary history of the bivalve Subclass Anomalodesmata. Journal of Paleontology, v. 48, p. 904-939, 1974.

RUNNEGAR, B.; NEWELL, N. D. Caspian-like relict molluscan fauna in South American Permian. Bulletin of the American Museum of Natural History, v. 146, p. 1-66, 1971.

SEILACHER, A. General remarks about event deposits. In: EINSELE, G.; SEILACHER, A. Cyclic and Event Stratification. Berlin: Springer, 1982. p. 161-174.

SEILACHER, A.; REIF, W. E.; WESTPHAL, F. Sedimentological, ecological and temporal patterns of fossil Lagerstatten. Philosophical Transactions Royal Society London B, v. 311, p. 5- 23, 1985.

SIMÕES, M. G.; ANELLI, L. E. Runnegariella, um novo gênero de Megadesmidae (Pelecypoda) da Formação Corumbataí (Neopermiano), Bacia do Paraná, Brasil. Revista Geociências, v. 14, p. 161-173, 1995.

SIMÕES, M. G.; KOWALEWSKI, M. Shell beds as paleoecological puzzles: a case study from the Upper Permian of the Paraná Basin, Brazil. Facies, v. 38, p. 175-196, 1998.

SIMOES, M. G.; TORELLO, F. F. Modelo de tafofácies para os moluscos bivalves do Grupo Passa Dois (Formações Serra Alta, Teresina e Corumbataí), Permiano Superior, Bacia do Paraná, Brasil. Revista Brasileira de Geociências, v. 33, p. 1-10, 2003.
SIMÕES, M. G.; TORELLO, F. F.; ROCHA-CAMPOS, A. C. Gênese e classificação da coquina de Camaquã, Formação Corumbataí (Neopermiano), na Região de Rio Claro, SP. Anais da Academia Brasileira de Ciências, v. 68, p. 545-557, 1996.

SIMÕES, M. G.; ROCHA-CAMPOS, A. C.; ANELLI, L. E. Paleoecology and evolution of Permian pelecypod assemblages (Paraná Basin) from Brazil. In: JOHNSTON, P. A.; HAGGART, J. W. (Ed.) Bivalves - An Eon of evolution: paleobiological studies honoring Norman D. Newell. Calgary: University of Calgary Press, 1998. p. 443-452.

SIMÕES, M. G.; KOWALEWSKI, M.; TORELLO, F. F.; GHILARDI, R. P.; MELLO, L. H. C. Early onset of Modern-Style shell beds in the Permian sequences of the Parana basin: implications for the Phanerozoic trend in bioclastic accumulations. Revista Brasileira de Geociências, v. 30, p. 499-503, 2000.

SIMÕES, M. G.; MARQUES, A. C.; MELLO, L. H. C.; ANELLI,L.E.Philogenetic analysis of the genera of the extinct family Megadesmidae (Pelecypoda, Anomalodesmata), with remarks on its paleoecology and taxonomy. Journal of Comparative Biology, v. 2, p. 75-90, 1997.

STANLEY, S. M. Relation of shell form to life habitats of the Bivalvia (Mollusca). Memoir of the Geological Society of America, v. 125, p. 1-296, 1970.

STANLEY, S. M. Functional morphology and evolution of byssally attached bivalve mollusks. Journal of Paleontology, v. 46, n. 2, p. 165-212, 1972.

TORELLO, F. F.; SIMÕES, M. G. Características tafonômicas da assembléia de Pinzonella illusa Reed, Formação Corumbataí (Neopermiano), Bacia do Paraná, Brasil. Acta Geologica Leopoldensia, v. 39, p. 159-173, 1994.

WARREN, L. V.; ALMEIDA, R. P.; HACHIRO, J.; MACHADO, R.; ROLDAN, L. F.; STEINER, S. S.; CHAMANI, M. A. C. Evolução sedimentar da Formação Rio do Rastro (Permo-Triássico da Bacia do Paraná) na porção centro sul do estado de Santa Catarina, Brasil. Revista Brasileira de Geociências, v. 38, n. 2, p. 213-227, 2008. 